\title{
Antifungal activity of essential oils from Cinnamomum cassia, Myristica fragrans and Syzygium aromaticum against Rhodotorula mucilaginosa
}

\author{
Juliana Caroline Butzge*a, Simone Krause Ferrão ${ }^{\mathrm{a}}$, Leticia Mezzomo ${ }^{\mathrm{b}}$, Luciane Noal Calil ${ }^{\mathrm{b}}$, Adelina Mezzari ${ }^{\mathrm{b}}$, \\ Renata Pereira Limberger ${ }^{\mathrm{a}, \mathrm{b}}$, Miriam Anders Apel ${ }^{\mathrm{a}, \mathrm{b}}$ \\ aPrograma de Pós-Graduação em Ciências Farmacêuticas, Faculdade de Farmácia, Universidade Federal do \\ Rio Grande do Sul (UFRGS), Porto Alegre, RS, Brazil; ${ }^{b}$ Departamento de Análises Clínicas Faculdade de \\ Farmácia, Universidade Federal do Rio Grande do Sul (UFRGS), Porto Alegre, RS, Brazil
}

*Corresponding author: jcbutzge@gmail.com

\begin{abstract}
Rhodotorula genus comprises yeasts from Sporidiobolaceae family. Considered as non-pathogenic until the last two decades, different species of Rhodotorula are emerging as human pathogens. Rhodotorula mucilaginosa is the most prevalent species commonly involved in infections which range from simpler clinical conditions such as skin manifestations to more severe cases as meningitis and endocarditis. The major facilitating agents for the emergence of these infections are invasive procedures such as catheter implants. The primary drugs of choice used to treat these infections are amphotericin B and fluconazole. However, some strains of this yeast show different degrees of resistance to these substances, thus justifying the search for new therapeutic agents. Considering this, the present study aims the investigation of the antifungal activity of the essential oils of Cinnamomum cassia (cinnamon), Syzygium aromaticum (clove) and Myristica fragrans (nutmeg) against clinical isolates of $R$. mucilaginosa. The essential oils were obtained by hydrodistillation and characterized by GC-MS. The investigation of the antifungal activity was performed by the agar discdiffusion test followed by the Minimum Inhibitory Concentration (MIC) determination. All the essential oils are characterized by the presence of phenylpropanoids, with eugenol (77.6 to $94.4 \%$ ) as the main compound of clove and $E$ cinnamaldehyde $(90.4$ to $100 \%)$ of cinnamon. Nutmeg oil is characterized by the presence of the phenylpropanoids myristicin (1.8 to $12.8 \%$ ) and elemicin ( 4.3 to $11.1 \%$ ), besides the monoterpenes sabinene ( 28.2 to $44.4 \%$ ) and terpinen-4ol $(16.0$ to $19.5 \%)$. In the investigation of antifungal activity, all the oils showed potential action against clinical isolates of $R$. mucilaginosa, with MICs ranging from 8 to $500 \mu \mathrm{g} / \mathrm{mL}$. The results demonstrate that these oils are promising candidates in the search for new anti-Rhodotorula agents, enabling the treatment of aforementioned infections.
\end{abstract}

Keywords: Rhodotorula mucilaginosa, essential oils, antifungal.

https://doi.org/10.22456/2527-2616.104615

\section{Introduction}

Rhodotorula is a yeast fungus commonly found in nature. It can be found in different types of samples, such as soil, water, milk, fruit juices, and in the air. Although it has been considered a non-pathogenic microorganism until the last two decades, different species of Rhodotorula are emerging as human pathogens. Invasive procedures such as catheter implantation, especially in immunosuppressed patients, are a major factor in the emergence of secondary infections, such as fungemias, endocarditis, meningitis, peritonitis, among others (1).

Rhodotorula spp. appear to be more frequent in tropical regions (2). The first case of fatal endocarditis attributed to species of this genus was published in the 1960s in a 47-year-old rheumatic woman with heart disease (3). Since then, other reports of infection in humans have been described in the scientific literature, mainly in the last two decades (4). Rhodotorula mucilaginosa is the most commonly involved in human infections, followed by $R$. glutinis and $R$. minuta (2). The first choice of treatment involves the administration of amphotericin B and fluconazole. A study conducted by Franconieri et al. (5), including eleven case studies of peritonitis caused by $R$. mucilaginosa, found that amphotericin B and fluconazole had the strongest anti-Rhodotorula mucilaginosa activity. The tests performed to check its presence allow the visualization of the growth of its colonies after 24 to 48 hours of incubation, commonly showing smooth and mucous, reddish-orange appearance in Sabouraud dextrose agar culture medium with chloramphenicol. The maximum growth temperature varies from 25 to $37{ }^{\circ} \mathrm{C}$ $(6,7)$.

Cinnamomum cassia (L.) J. Presl (cinnamon-of-china) is an aromatic plant, belonging to the Lauraceae family widely used in cooking and fragrance production (8). It originates in China and is widely cultivated in Indonesia, India, Malaysia, Laos, Taiwan, Thailand, and Vietnam (9). In folk medicine, it is used to treat inflammatory processes, fever, and hypertension. The essential oil has exhibited antifungal and antibacterial activity, in addition anti-inflammatory, antioxidant, anti-tyrosinase actions, among others (10-15). Regarding $E$-cinnamaldehyde, the main component of essential oil, the anti-inflammatory and antioxidant (16), antifungal (17) and antibacterial (18) activities have been proven.

Syzygium aromaticum L. Merr. \& L.M. Perry (clove) is a large tree (12 to 15 meters tall), belonging to the Myrtaceae family and widely cultivated in Tanzania, Brazil, Sri Lanka, Indonesia, and Madagascar (19). It has 
been popularly used due to its flavoring properties, in food preservation, oral hygiene products, and also in gastrointestinal disorders. Several studies show its importance as a bactericidal and fungicidal, antioxidant, and anti-inflammatory agent, among others (20-23). The antimicrobial activity observed may be related to eugenol, the main constituent of the essential oil of the floral bud of $S$. aromaticum, a compound for which antimicrobial activities have already been proven (24-26), in addition to anti-inflammatory and antioxidant (16).

Myristica fragrans Houtt. (nutmeg) is a tree in the Myristicaceae family that can reach up to 12 meters in height as an adult (27). The largest producer is Indonesia, followed by Granada, Sri Lanka and Trinidad and Tobago (28). This species has been used in cooking as a food spice, as a flavoring and also in treatments for diseases such as stomach pain, rheumatism and vomiting during pregnancy (29). For the nutmeg essential oil, antimicrobial, antiseptic, antiparasitic, anti-inflammatory and antioxidant activities have been demonstrated (2932). To date, there are no reports in the specialized literature describing the action of these species against Rhodotorula mucilaginosa. Thus, this work aims to extract the essential oils from Cinnamomum cassia, Syzygium aromaticum and Myristica fragrans, perform their chemical characterization through GC-MS and evaluate their antifungal activity against $R$. mucilaginosa, looking for new antifungal prospects for the market.

\section{Materials and Methods}

\section{Samples}

Samples of Cinnamomum cassia (barks), Syzygium aromaticum (floral bud), and Myristica fragrans (fruits) were commercially acquired in the state of Rio Grande do Sul. The oils were obtained by hydrodistillation in a Clevenger type apparatus, according to the methodology recommended by the Brazilian Pharmacopoeia $6^{\text {th }}$ ed. (2019).

The microorganisms used in this study are clinical isolates of $R$. mucilaginosa resistant to classic antifungals (approval by the Ethics Committee No. 4.069.576, CEPUFRGS), provided by the Biomicolab Laboratory (Mycology Laboratory of the Federal University of Rio Grande do Sul). Five clinical isolates of $R$. mucilaginosa were selected. The stock cultures were kept in freezing soybean trypticase broth (TSB; Himedia ${ }^{\circledR}$ ) plus $10 \%$ glycerol at $-18^{\circ} \mathrm{C}$. To reactivate the strains, $10 \mu \mathrm{L}$ of the stock culture were inoculated into tubes containing Sabouraud dextrose agar with chloramphenicol (Kasvi®) and incubated at $30{ }^{\circ} \mathrm{C}$ for $48-\mathrm{h}$. As positive controls, fluconazole (Polydrug Laboratorie Private Limited/India), ketoconazole (Aairt Drugs Limited/India), amphotericin B (North China Pharmaceutical/China) and itraconazole (Cecon/Brazil) were used.

\section{Essential Oils Chemical Analysis}

For chromatographic analysis, the oils obtained were diluted to $2 \%$ in ethyl ether (v/v) (Tédiaß). The analysis was performed using a gas chromatograph coupled to a mass detector (GC-MS), model Shimadzu QP5000, equipped with a capillary column of fused silica Durabond-DB-5 (John Wiley \& Sons Scientific, US, 30 $\mathrm{m} \times 0.25 \mathrm{~mm} \times 0.25 \mu \mathrm{m})$ for separating the constituents. The source temperature, quadrupole and injector were set at $230{ }^{\circ} \mathrm{C}, 150{ }^{\circ} \mathrm{C}$ and $220{ }^{\circ} \mathrm{C}$, respectively. Detector temperature was set at $250{ }^{\circ} \mathrm{C}$. The column temperature was programmed with a heating ramp from $60^{\circ} \mathrm{C}$ to 300 ${ }^{\circ} \mathrm{C}$ with an increase of $3{ }^{\circ} \mathrm{C} / \mathrm{min}$, using ultrapure helium as the carrier gas at $80 \mathrm{kPa}$ and flow of $1 \mathrm{~mL} / \mathrm{min}$. The mass detector was operating at $70 \mathrm{eV}$.

The components were identified by comparing their relative retention index, calculated by relative linear interpolation for the retention time of a series of $n$-alkanes $\left(\mathrm{C}_{8}\right.$ to $\left.\mathrm{C}_{32}\right)$, and their mass spectrum, with data obtained in the literature (33), as well as, by comparison with mass spectrums of the acquisition spectrotheca (NIST 62 and 12 - National Institute of Standards and Technology, Kyoto, JP) and standards from our research group repository. Relative amounts of each compound were calculated from the peak areas by normalization.

\section{Antifungal Activity}

Initially, antifungal activity against $R$. mucilaginosa was investigated by the paper disc diffusion technique (Kirby Bauer method). The tests were performed on sterile Petry plates containing Sabouraud agar. In summary, a suspension in yeast Sabouraud agar (90\%) was spread on the plate agar. Paper discs were impregnated with $15-\mu \mathrm{L}$ of the essential oil and placed on the surface of the previously inoculated medium. The plates were incubated in an oven at $37^{\circ} \mathrm{C}$ and the inhibition halos were read after 48-h. The measurement scale was as follows: the zone of inhibition $>15 \mathrm{~mm}$ was considered to be strongly inhibitory; the zone of inhibition 10-15 mm moderately inhibitory and $<10 \mathrm{~mm}$ non-inhibitory (34). The test was performed in duplicate. The essential oils that exhibited strong inhibition were subjected to the test to determine the Minimum Inhibitory Concentration (MIC). As for antifungals, it was performed with the itraconazole disc to verify the antifungal action of this compound on the yeast $R$. mucilaginosa.

The determination of the Minimum Inhibitory Concentration (MIC) against $R$. mucilaginosa was carried out by the broth microdilution method, as recommended by the Clinical and Laboratory Standards Institute - CLSI (35). The oils were dissolved in dimethyl sulfoxide DMSO (Nuclear®). The concentration range used for essential oils was 0.488 to $1000 \mu \mathrm{g} / \mathrm{mL}$ (36). The $R$. mucilaginosa culture (103 CFU/mL) in RPMI 1640 (Sigma Aldrich $®$ ) was added to the microplate wells to detect the action of the oil. The microplates were incubated at $30{ }^{\circ} \mathrm{C}$ and inspected after 24 and $48 \mathrm{~h}$ for visual verification of growth $(35,37,38)$. The experiment 
was carried out in duplicate. MIC was considered to be the lowest concentration of oil capable of completely inhibiting microbial growth visible to the naked eye. For results evaluation, the following cut-off points were used for the antifungals tested according to CLSI: fluconazole: sensitive (S) $\leq 8 \mu \mathrm{g} / \mathrm{mL}$, dose-dependent sensitive (SDD) $16-32 \mu \mathrm{g} / \mathrm{mL}$, resistant $(\mathrm{R})>64 \mu \mathrm{g} / \mathrm{mL}$; itraconazole: $\mathrm{S} \leq$ $0.12 \mu \mathrm{g} / \mathrm{mL}, \quad$ S-DD $0.25-0.5 \mu \mathrm{g} / \mathrm{mL}, \quad \mathrm{R}>1 \mu \mathrm{g} / \mathrm{mL}$; amphotericin B: $\mathrm{R} \geq 1 \mu \mathrm{g} / \mathrm{mL}$ (37). For ketoconazole, the following cut-off point $\mathrm{S} \leq 1 \mu \mathrm{g} / \mathrm{mL}, \mathrm{S}-\mathrm{DD} 2-4 \mu \mathrm{g} / \mathrm{mL}, \mathrm{R}$ $>4 \mu \mathrm{g} / \mathrm{mL}$ was used.

\section{Results and Discussion}

The data regarding the samples are shown in Table 1.Three samples of cloves (identified by OSA1 to OSA3), five samples of cinnamon (OCC1 to OCC5) and two of nutmeg (OMF1 and OMF2) were considered. The percentage yield was calculated by the relationship between the volume of oil obtained by the dry mass of the plant. Considering the levels of essential oil obtained, there are some peculiarities, as in the case of Syzygium aromaticum, with a high variation in the oil content obtained from the three commercial samples (average of $9.8 \pm 4.03 \%$ ). This result may be related to the supplier, as the samples OSA1 and OSA2 are from the same supplier and have the highest levels. Here, different suppliers may be associated with the variation of producers, of the storage conditions, among other factors that can be related to the yield variation. Regarding the average value of yield obtained, Kapadiya and Desai (39) obtained $11.35 \%$ yield for the essential oil extracted from the referred plant, corroborating the average value obtained in the present study.

Table 1. Percentage yield of essential oils obtained by hydrodistillation from Syzygium aromaticum (floral bud), Cinnamomum cassia (barks) and Myristica fragrans (fruits).

\begin{tabular}{lcccc}
\hline Species & $\begin{array}{c}\text { Sup } \\
\text { plier }\end{array}$ & $\begin{array}{c}\text { Acquisition } \\
\text { date }\end{array}$ & $\begin{array}{c}\text { Expiration } \\
\text { date }\end{array}$ & $\begin{array}{c}\text { Yield } \\
{[\%, \mathbf{p} / \mathbf{v}]}\end{array}$ \\
\hline S. aromaticum & & & & \\
OSA1 & $\mathrm{A}$ & $18 / 09 / 2018$ & $19 / 03 / 2020$ & 14.1 \\
OSA2 & $\mathrm{A}$ & $02 / 10 / 2018$ & $11 / 03 / 2020$ & 9.3 \\
OSA3 & $\mathrm{B}$ & $03 / 10 / 2018$ & Not informed & 6.1 \\
\hline C. cassia & & & & \\
OCC1 & $\mathrm{A}$ & $12 / 09 / 2018$ & $20 / 07 / 2020$ & 0.5 \\
OCC2 & $\mathrm{C}$ & $14 / 09 / 2018$ & $01 / 08 / 2020$ & 0.2 \\
OCC3 & $\mathrm{A}$ & $26 / 09 / 2018$ & $11 / 06 / 2020$ & 0.3 \\
OCC4 & $\mathrm{A}$ & $27 / 09 / 2018$ & $11 / 06 / 2020$ & 0.2 \\
OCC5 & $\mathrm{A}$ & $28 / 09 / 2018$ & $20 / 07 / 2020$ & 0.5 \\
\hline M. fragrans & & & & \\
OMF1 & $\mathrm{A}$ & $24 / 09 / 2018$ & $12 / 06 / 2020$ & 1.7 \\
OMF2 & $\mathrm{D}$ & $25 / 09 / 2018$ & $06 / 07 / 2019$ & 2.6 \\
\hline
\end{tabular}

For the samples of Cinnamomum cassia, it is observed that the variation was not so great, presenting an average yield of $0.3 \pm 0.14 \%$. This value is close to that found in the literature. Tao et al. (40) obtained an average yield of $1.48 \%$ in the essential oil extracted from Cinnamomum cassia. Considering the suppliers there is no difference among them. Finally, for Myristica fragrans, the two samples showed a difference in their essential oil yield value with an average of $2.1 \pm 0.64 \%$, which may be related also to the supplier. This yield value is slightly below that reported in the literature for that plant (41). Regarding the expiration date, all samples were within the validity period (the ones that had this information).

The chemical characterization of essential oils obtained by hydrodistillation was performed by GC-MS. The results are described in Table 2. All the species selected for this study are characterized by the presence of phenylpropanoids. The analysis of the Syzygium aromaticum samples highlighted the majority of eugenol (77.6 to $94.4 \%$ ) followed by its eugenyl acetate derivative (4.8 to 20.7\%). The samples of essential oil of Cinnamomum cassia presented $E$-cinnamaldehyde as the main constituent, sometimes accounting for the totality of the oil (90.4 to $100 \%)$. Finally, the essential oil of Myristica fragrans was characterized by the presence of myristicin (1.8 to $12.8 \%$ ) and elemicin (4.3 to $11.1 \%)$. In the oil of this species, monoterpenes were also present in large quantities, represented mainly by sabinene (28.2 to $44.4 \%$ ) and terpinen-4-ol (16.0 to $19.5 \%$ ).

Souza et al. (42) studied the chemical composition of 16 essential oils, including those extracted from Syzygium aromaticum, Cinnamomum cassia and Myristica fragrans. The results associated with the composition of $S$. aromaticum oil reported in that study showed that it was mainly composed of eugenol $(80.67 \%)$ and eugenyl acetate $(11.92 \%)$. These values corroborate the analysis carried out in the present study and reported in Table 2, where an average concentration of $84 \%$ eugenol and $15 \%$ eugenyl acetate was found in clove oils. Still, according to these same authors, the essential oil of Cinnamomum cassia is composed mainly of $E$-cinnamaldehyde $(84.52 \%)$, also in agreement with the results found in this study (Table 2), which verified an average value of $96.9 \%$ for the concentration of $E$-cinnamaldehyde. For oil extracted from Myristica fragrans, these authors also reported the presence of sabinene (16.54\%), terpinen-4-ol $(5.44 \%)$ and myristicin (15.1\%), among other constituents, however it was not reported the presence of elemicin, a compound that also characterizes the essential oil of $M$. fragrans. On the other hand, in a recent work involving the characterization of essential oil of this species (43) the presence of this compound with an average content of $9.93 \%$ was observed. According to Table 2, the $M$. fragrans oils analyzed showed average concentrations of $36.3 \%$ sabinene, $17.8 \%$ terpinen-4-ol, $7.3 \%$ myristicin and $7.7 \%$ for elemicin, which is consistent with the literature data. 
Table 2. Chemical characterization of essential oils obtained from different samples of Syzygium aromaticum, Cinnamomum cassia and Myristica fragrans by GC-MS.

\begin{tabular}{|c|c|c|c|c|c|c|c|c|c|c|c|}
\hline \multirow[t]{2}{*}{ RRI } & \multirow[t]{2}{*}{ Constituents } & \multicolumn{3}{|c|}{ Syzygium aromaticum } & \multicolumn{5}{|c|}{ Cinnamomum cassia } & \multicolumn{2}{|c|}{$\begin{array}{l}\text { Myristica } \\
\text { fragrans }\end{array}$} \\
\hline & & OSA1 & OSA2 & OSA3 & OCC1 & $\mathrm{OCC2}$ & $\mathrm{OCC3}$ & $\mathrm{OCC4}$ & OCC5 & OMF1 & OMF2 \\
\hline 923 & tricycle & - & - & - & - & - & - & - & - & 0.5 & 0.9 \\
\hline 926 & $\alpha$-thujene & - & - & - & - & - & - & - & - & 1.5 & 3.8 \\
\hline 928 & $\alpha$-pinene & - & - & - & - & - & - & - & - & 1.9 & 4.0 \\
\hline 962 & benzaldehyde & - & - & - & - & - & - & - & 1.7 & - & - \\
\hline 967 & sabinene & - & - & - & - & - & - & - & - & 28.2 & 44.4 \\
\hline 971 & $\beta$-pinene & - & - & - & - & - & - & - & - & 3.3 & 5.0 \\
\hline 990 & mycrene & - & - & - & - & - & - & - & - & 2.3 & 2.6 \\
\hline 1003 & $\alpha$-felandrene & - & - & - & - & - & - & - & - & 0.5 & 0.7 \\
\hline 1008 & $\delta$-3-carene & - & - & - & - & - & - & - & - & 1.2 & 1.7 \\
\hline 1014 & $\alpha$-terpinene & - & - & - & - & - & - & - & - & 2.0 & 2.2 \\
\hline 1022 & p-cimene & - & - & - & - & - & - & - & - & 0.9 & 0.8 \\
\hline 1025 & limonene & - & - & - & - & - & - & - & - & 7.0 & 7.9 \\
\hline 1055 & $\gamma$-terpinene & - & - & - & - & - & - & - & - & 3.9 & 3.9 \\
\hline 1085 & terpinolene & - & - & - & - & - & - & - & - & 1.2 & - \\
\hline 1184 & terpinen-4-ol & - & - & - & - & - & - & - & - & 19.5 & 16.0 \\
\hline 1281 & $\begin{array}{c}E- \\
\text { cinnamaldehyde }\end{array}$ & - & - & - & 98.0 & 93.2 & 100.0 & 100.0 & 90.4 & - & - \\
\hline 1365 & eugenol & 77.6 & 80.0 & 94.4 & - & - & - & - & - & - & - \\
\hline 1406 & $\beta$-caryophyllene & 1.6 & 0.5 & 0.9 & - & - & - & - & - & 1.9 & trace \\
\hline 1447 & $\begin{array}{l}\text { cinamyl } E \text { - } \\
\text { acetate }\end{array}$ & - & - & - & 2.0 & 0.2 & - & - & - & - & - \\
\hline 1487 & cinnamic acid & - & - & - & trace & - & trace & Trace & 7.9 & - & - \\
\hline 1519 & myristicin & - & - & - & - & - & - & - & - & 12.8 & 1.8 \\
\hline 1528 & eugenyl acetate & 20.7 & 19.6 & 4.8 & - & - & - & - & - & - & - \\
\hline 1538 & $\begin{array}{c}E \text {-o-methoxy } \\
\text { cinnamaldehyde }\end{array}$ & - & - & - & trace & - & & - & - & - & - \\
\hline 1556 & elemicin & - & - & - & - & - & - & - & - & 11.1 & 4.3 \\
\hline
\end{tabular}

Compounds listed in order of elution in DB5 column; RRI: relative retention index. OSA: essential oil of Syzygium aromaticum, OCC: essential oil of Cinnamomum cassia, OMF: essential oil of Myristica fragrans.

The investigation of antifungal activity was performed to verify the susceptibility of $\mathrm{R}$. mucilaginosa yeast to Syzygium aromaticum (OSA), Cinnamomum cassia (OCC) and Myristica fragrans (OMF) oils. Pooling was performed to determine the samples used in the test. Initially, a screening was carried out to select the samples that demonstrated action on yeast. For this purpose, the Kirby Bauer method was used which consists of impregnating paper discs with the oil samples to be tested. Itraconazole was used to check the susceptibility of the microorganism. The results obtained in this stage are shown in Figure 1, and Table 3 describes the diameters of the inhibition halos for each essential oil and for itraconazole. It can be seen that R. mucilaginosa was resistant to itraconazole, but sensitive to the three oils used. Thus, the three oils were sent to the next step, which consisted of determining the minimum inhibitory concentration (MIC). At this time, the antifungal agents itraconazole (ITR), amphotericin B (AMP), ketoconazole (KET), fluconazole (FLU) were also used to check yeast susceptibility.

The MIC for each sample was determined in duplicate and on two different days. The concentration ranges tested were: $0.488-1000 \mu \mathrm{g} / \mathrm{mL}$ for essential oil samples; 0.0312 - $16 \mu \mathrm{g} / \mathrm{mL}$ of ANF; $0.03-16 \mu \mathrm{g} / \mathrm{mL}$ CET; $0.125-64 \mu \mathrm{g} / \mathrm{mL}$ of FLU and $0.0312-16 \mu \mathrm{g} / \mathrm{mL}$ of ITR. MICs values were defined as the lowest concentration of oil and amphotericin B samples in which R. mucilaginosa did not show visible growth. For itraconazole (ITR), ketoconazole (CET), fluconazole (FLU) it was defined as being $50 \%$ of the positive control. This value represents the drug concentration that inhibits the growth of $50 \%$ of the isolates. In general, all essential oils tested showed promising activity, with MICs ranging from 8 to $500 \mu \mathrm{g} / \mathrm{mL}$ (Table 3).

Table 3. Inhibition halos size (values in $\mathrm{mm}$ ) of the Syzygium aromaticum, Cinnamomum cassia and Myristica fragrans essential oils and Itraconazole against five clinical isolates of the yeast $R$. mucilaginosa.

\begin{tabular}{ccccc}
\hline Clinical isolate & OSA & OCC & OMF & ITR \\
\hline$\# 1$ & 28 & 40 & 15 & $\mathrm{R}$ \\
$\mathbf{\# 2}$ & 25 & 40 & 18 & $\mathrm{R}$ \\
$\mathbf{\# 3}$ & 25 & 40 & 10 & $\mathrm{R}$ \\
$\mathbf{\# 4}$ & 30 & 40 & 15 & $\mathrm{R}$ \\
$\mathbf{\# 5}$ & 35 & 40 & 20 & $\mathrm{R}$ \\
\hline
\end{tabular}

OSA: essential oil of Syzygium aromaticum, OCC: essential oil of Cinnamomum cassia, OMF: essential oil of Myristica fragrans. ITR: itraconazole. R: resistant.

Considering the classic antifungals, it was observed that all clinical isolates were resistant. It is interesting to note 
the difference in response according to the clinical isolate, which can be related to variations in intrinsic or acquired resistance, possibly induced by the environment. Among the essential oil samples tested, the one that showed the best result was Cinnamomum cassia, for which all clinical isolates tested were susceptible, with a MIC value of $8 \mu \mathrm{g} / \mathrm{mL}$ being observed. The oil of Myristica fragrans showed the best result for isolate 4 (MIC $8 \mu \mathrm{g} / \mathrm{mL}$ ). The oil of Syzygium aromaticum showed action against all isolates, with MIC ranging from 62 to $125 \mu \mathrm{g} / \mathrm{mL}$.

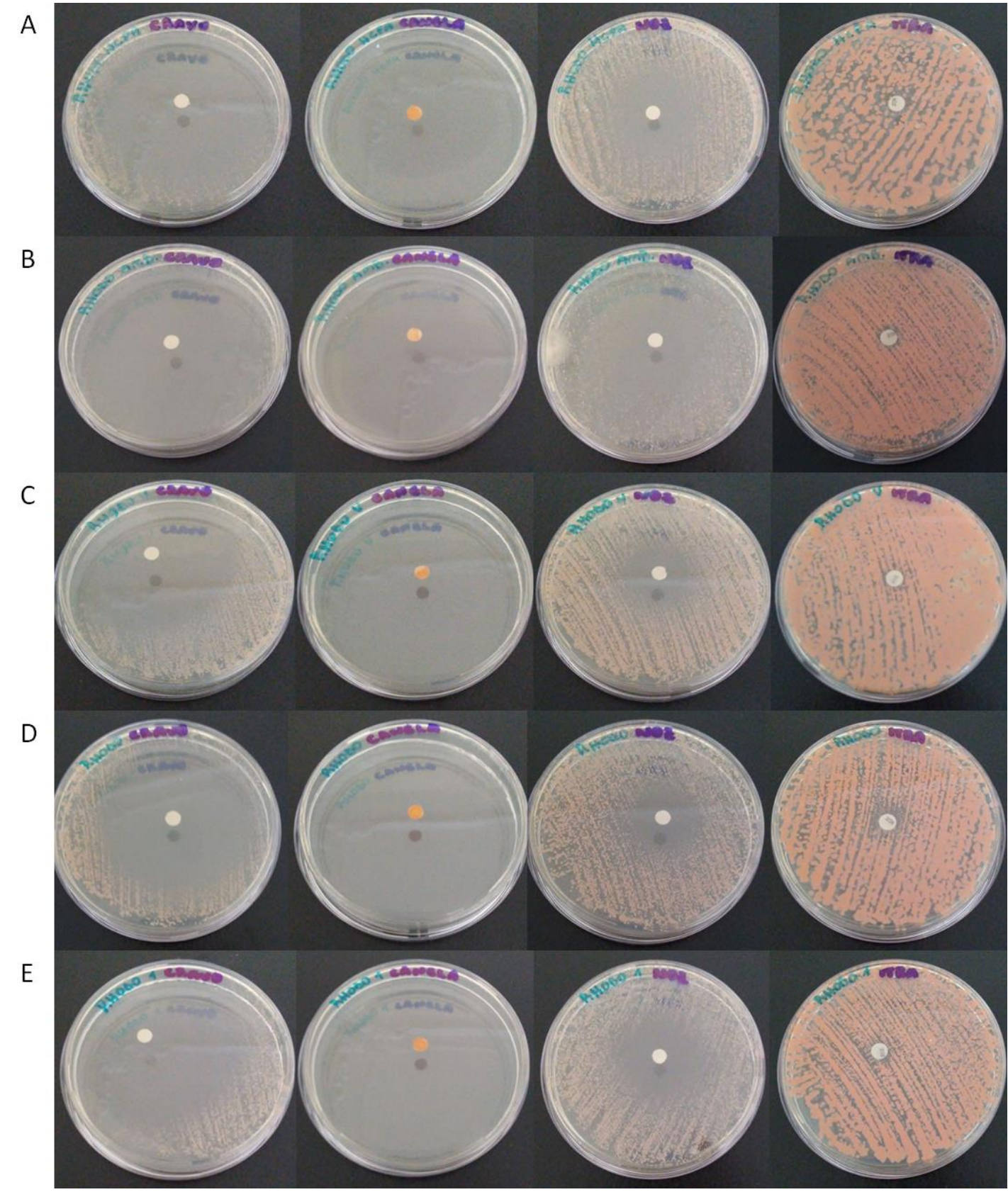

Figure 1. A) Results associated with clinical isolate 1 from essential oil of Syzygium aromaticum L. Merr. (OSA), Cinnamomum cassia (L.) J. Presl (OCC), Myristica fragrans Houtt (OMF) and itraconazole (ITR), from left to right, respectively; B) results associated with clinical isolate 2 from OSA, OCC, OMF and ITR; C) results associated with clinical isolate 3 from OSA, OCC, OMF and ITR; D) results associated with clinical isolate 4 from OSA, OCC, OMF and ITR; E) results associated with clinical isolate 5 from OSA, OCC, OMF and ITR.

The essential oil extracted from Cinnamomum cassia has been the subject of scientific studies due to its biological properties. In a study conducted by Cavalcanti and Almeida (10), the oil of this species demonstrated antifungal activity against strains of Candida albicans isolated from HIV positive patients and standard strain (ATCC 76845), with a MIC value of $64 \mu \mathrm{g} / \mathrm{mL}$ being observed for the most part of the strains analyzed. MA et al. (9), have already proved the antifungal property of $C$. cassia oil against pathogenic fungi present in Panax 
notoginseng, a plant widely used in traditional Chinese medicine. Research specifically focused on the action of cinnamaldehyde has shown action against Malassezia pachydermatis with MIC of up to $2.5 \mu \mathrm{g} / \mathrm{mL}$ (44) and against clinical isolates of Candida resistant to fluconazole, presenting MIC of 90 up to $100 \mu \mathrm{g} / \mathrm{mL}$ (45). Such results corroborate those presented in this work, where there was a potential antifungal action of the essential oil of $C$. cassia against $R$. mucilaginosa. Considering that some of the tested samples present the oil composed of $100 \%$ E-cinnamaldehyde, it can be said that this phenylpropanoid is responsible for the action observed against $R$. mucilaginosa.

Several scientific studies have reported the antifungal activity of the essential oil obtained from Syzygium aromaticum (46-50). Rajkowska et al. (50), for example, evaluated the antifungal action of Syzygium aromaticum against nine species of Candida, with MIC values varying between 0.03 and $8 \%$. In the research conducted by Pinto et al. (48), antifungal activity of $S$. aromaticum oil was confirmed against strains of some species of Candida, Aspergillus and dermatophytes. As reported, these results were related to the high concentration of eugenol present in the essential oil. In another study, the action of eugenol alone against Candida albicans and in combination with amphotericin B was demonstrated, showing synergistic potential, enabling the use of lower concentrations of this substance in the treatment of $C$. albicans (51). Such findings are in agreement with the results presented in this work, demonstrating the potential antifungal effect of the oil against several species of fungi.

The antifungal action of Myristica fragrans essential oils has also been demonstrated against strains of Aspergillus niger, Fusarium axysporum, Pinicillium glabrum, Rhizopus oryzae and Mucor recemosus (28) as well as against Candida albicans (52). These results corroborate the present study, where antifungal activity against Rhodotorula mucilaginosa was also proven (Table 4).

Table 4. Minimum Inhibitory Concentration (MIC) (values in $\mu \mathrm{g} / \mathrm{mL}$ ) of the Syzygium aromaticum, Cinnamomum cassia and Myristica fragrans essential oils against five clinical isolates of the yeast $R$. mucilaginosa.

\begin{tabular}{|c|c|c|c|c|c|c|c|}
\hline $\begin{array}{c}\text { Clinica } \\
1 \\
\text { isolate }\end{array}$ & $\begin{array}{c}\text { OS } \\
\mathbf{A}\end{array}$ & $\begin{array}{c}\mathbf{O C} \\
\mathbf{C}\end{array}$ & $\underset{\mathbf{F}}{\mathbf{O M}}$ & $\underset{\mathbf{P}}{\mathbf{A M}}$ & $\begin{array}{c}\mathbf{K E} \\
\mathbf{T}\end{array}$ & $\begin{array}{c}\mathbf{F L} \\
\mathbf{U}\end{array}$ & $\begin{array}{c}\text { IT } \\
\mathbf{R}\end{array}$ \\
\hline$\# 1$ & 250 & 62 & 500 & 16 & 16 & 64 & 16 \\
\hline$\# 2$ & 62 & 125 & 500 & 64 & 16 & 64 & 16 \\
\hline$\# \mathbf{3}$ & 125 & NT & 500 & 64 & 16 & 64 & 16 \\
\hline$\# 4$ & 62 & 31 & 8 & 64 & 16 & 64 & 16 \\
\hline$\# 5$ & 125 & 8 & 31 & 16 & 16 & 64 & 16 \\
\hline
\end{tabular}

OSA: essential oil of Syzygium aromaticum, OCC: essential oil of Cinnamomum cassia, OMF: essential oil of Myristica fragrans. AMP: amphotericin B, KET: ketoconazole, FLU: fluconazole; ITR: itraconazole. NT: not tested.

Some studies have shown that essential oils that contain cinnamaldehyde, thymol, carvacrol or eugenol have high antimicrobial activity $(42,53)$. Thus, the presence of $E$ cinnamaldehyde and eugenol identified in the chemical composition of the Cinnamomum cassia and Syzygium aromaticum essential oils, respectively, may be associated with the potential antifungal activity against $R$. mucilaginosa observed in the present study, aiming at the prospect of new therapeutic agents.

It has already been found that the same essential oil can present different antifungal activity and mechanism of action when it is tested against different pathogens $(54,55)$. Such a result may be associated with the complexity and diversity of antifungal mechanisms (9). According to studies in the field, the mechanism of antifungal action of the Cinnamomum cassia essential oil may be associated with the $\mathrm{CHO}$ group present in the molecule of the cinnamaldehyde. Thus, considering the fact that $\mathrm{CHO}$ group is hydrophilic, the cinnamaldehyde can easily absorb the hydrophilic constituents of the surface of the fungi, facilitating its penetration into the cell wall and, consequently, causing the death of the cell (9). For the essential oil of Syzygium aromaticum, the mechanism of antifungal action may be related to eugenol, its main constituent, and its ability to disturb the integrity and permeability of the fungal cell membrane, which may cause irreversible damage to the cell. In addition, such a constituent can destroy yeast proteins and inhibit their synthesis (56). The presence of phenylpropene terpinen-4-ol and phenylpropanoid elemicin among the main constituents of Myristica fragrans essential oil may be related to the antifungal action verified for this substance in the present study. According to results reported in the literature, the mechanism of antifungal action of phenylpropenes is potentially associated with their lipophilicity, which allows them to act on the permeability of the cell membrane, in addition to inhibiting specific cellular processes or enzymes (57).

\section{Conclusions}

This study reports for the first time the activity of the essential oil extracted from Syzygium aromaticum, Cinnamomum cassia and Myristica fragrans against clinical isolates of $R$. mucilaginosa, demonstrating the originality of the study. The observed results allowed to verify the potential effect of the tested oils against this yeast, presenting MIC of up to $8 \mu \mathrm{g} / \mathrm{mL}$. Chemically, the essential oils of these species are characterized by the presence of phenylpropanoids such as eugenol, $E$ cinnamaldehyde, myristicin and elemicin, and phenylpropene as terpinen-4-ol, compounds with recognized antifungal action and that are probably responsible for the observed action. Thus, the results presented in this article are promising and justify the continuation of the work in this area. As a proposal for future work is the analysis of the genotoxicity of oils extracted from these plants.

\section{Acknowledgments}

The authors would like to thank the Conselho Nacional de Desenvolvimento Científico e Tecnológico - Brasil 
(CNPq) and the Coordenação de Aperfeiçoamento de Pessoal de Nivel Superior - Brasil (CAPES) for their financial support and scholarships.

\section{Conflict of interest}

The authors declare no conflicts of interest.

\section{References}

1.Wirth F, Goldani LZ. Epidemiology of Rhodotorula: An Emerging Pathogen. Interdiscip Perspect Infect Dis. 2012;1-7.

2.Alves KP. Realidade e desafios de infecções emergentes por Rhodotorula spp. em pacientes hospitalizados. Universidade Federal de Santa Catarina; 2019.

3.Louria DB, Greenberg SM, Molander DW. Fungemia caused by certain nonpathogenic strains of the family Cryptococcaceae. N Engl J Med. 1960;263(25):12814.

4.Tuon FF, Duboc de Almeida GM, Costa SF. Central venous catheter-associated fungemia due to Rhodotorula spp. - A systematic review. Med Mycol. 2007;45(5):441-7.

5.Franconieri F, Bonhomme J, Doriot A, Bonnamy C, Ficheux M, Lobbedez $\mathrm{T}$, et al. Fungal peritonitis caused by Rhodotorula mucilaginosa in a CAPD patient treated with liposomal amphotericin B: A case report and literature review. Perit Dial Int. 2018;38(1):69-73.

6.Rippon JW. Medical Mycology: The Pathogenic Fungi and the Pathogenic Actinomycetes. Philadelphia: W B Saunders Co; 1992. 707-729 p.

7.De Hoog GS, Guarro J, Gene J, Figueras MJ. Atlas of clinical fungi. 2nd ed. Amer Society for Microbiology; 2001. 1160 p.

8.Gomes MC, Firmino AV, de Almeida SSM da S. Eeito inibitório in vitro de extratos de Cinnamomum zeylanicum blume no controle de Cylindrocladium candelabrum. Ciência Florest. 2018;28(4):1559-67.

9.Ma YN, Chen CJ, Li Q, Wang W, Xu FR, Cheng YX, et al. Fungicidal activity of essential oils from Cinnamomum cassia against the pathogenic fungi of Panax notoginseng diseases. Chem Biodivers. 2019;16(11).

10.Almeida LFD, Cavalcanti YW, Castro RD, Lima EO. Atividade antifúngica de óleos essenciais frente à Candida albicans isoladas de pacientes HIV positivos. Rev Bras Plantas Med. 2011; (Atcc 76845):649-55.
11.Chang CT, Chang WL, Hsu JC, Shih Y, Chou ST. Chemical composition and tyrosinase inhibitory activity of Cinnamomum cassia essential oil. Bot Stud. 2013;54(1):2-8.

12.Chou ST, Chang WL, Chang CT, Hsu SL, Lin YC, Shih Y. Cinnamomum cassia essential oil inhibits $\alpha$ MSH-induced melanin production and oxidative stress in murine B16 melanoma cells. Int J Mol Sci. 2013;14(9):19186-201.

13.Sun L, Zong SB, Li JC, Lv YZ, Liu LN, Wang ZZ, et al. The essential oil from the twigs of Cinnamomum cassia Presl alleviates pain and inflammation in mice. J Ethnopharmacol [Internet]. 2016;194:904. Available from: http://dx.doi.org/10.1016/j.jep.2016.10.064

14.Raffaella C, Casettari L, Fagioli L, Cespi M, Bonacucina G, Baffone W. Activity of essential oilbased microemulsions against Staphylococcus aureus biofilms developed on stainless steel surface in different culture media and growth conditions. Int J Food Microbiol [Internet]. 2017;241:132-40. Available from: https://doi.org/10.1016/j.ijfoodmicro.2016.10.021

15.Veloso DJ, Abrão F, Martins CHG, Bronzato JD, Gomes BPFA, Higino JS, et al. Potential antibacterial and anti-halitosis activity of medicinal plants against oral bacteria. Arch Oral Biol. 2020;110.

16. Mateen S, Shahzad S, Ahmad S, Naeem SS, Khalid S, Akhtar K, et al. Cinnamaldehyde and eugenol attenuates collagen induced arthritis via reduction of free radicals and pro-inflammatory cytokines. Phytomedicine [Internet]. 2018;53:70-8. Available from: https://doi.org/10.1016/j.phymed.2018.09.004

17.Sun Q, Li J, Sun Y, Chen Q, Zhang L, Le T. The antifungal effects of cinnamaldehyde against Aspergillus niger and its application in bread preservation. Food Chem [Internet]. 2020;317:1-31. Available from: https://doi.org/10.1016/j.foodchem.2020.126405

18.Kenawy E, Omer AM, Tamer TM, Elmeligy MA, Eldin MSM. International Journal of Biological Macromolecules Fabrication of biodegradable gelatin / chitosan / cinnamaldehyde crosslinked membranes for antibacterial wound dressing applications. Int $\mathrm{J}$ Biol Macromol [Internet]. 2019;139:440-8. Available from: https://doi.org/10.1016/j.ijbiomac.2019.07.191

19.Ferrao JEM. Especiarias: cultura, tecnologia, comercio. Lisboa: Instituo de Investigacao Cientifica Tropical; 1993.

20.De Oliveira RA, Reis TV, Do Sacramento CK, Duarte 
LP, De Oliveira FF. Constituintes químicos voláteis de especiarias ricas em eugenol. Brazilian J Pharmacogn. 2009;19(3):771-5.

21.Beltrán-Villalobos KL, Déciga-Campos M, AguilarMariscal H, González-Trujano ME, Martínez-Salazar MF, Ramírez-Cisneros M de los Á, et al. Synergistic antinociceptive interaction of Syzygium aromaticum or Rosmarinus officinalis coadministered with ketorolac in rats. Biomed Pharmacother [Internet]. 2017;94:858-64. Available from: http://dx.doi.org/10.1016/j.biopha.2017.07.166

22.Ma YN, Xu FR, Chen CJ, Li QQ, Wang MZ, Cheng YX, et al. The beneficial use of essential oils from buds and fruit of Syzygium aromaticum to combat pathogenic fungi of Panax notoginseng. Ind Crops Prod [Internet]. 2019;133(November 2018):185-92. Available https://doi.org/10.1016/j.indcrop.2019.03.029

23.Radünz M, da Trindade MLM, Camargo TM, Radünz AL, Borges CD, Gandra EA, et al. Antimicrobial and antioxidant activity of unencapsulated and encapsulated clove (Syzygium aromaticum, L.) essential oil. Food Chem [Internet]. 2019;276:180-6. Available from: https://doi.org/10.1016/j.foodchem.2018.09.173

24.Guimarães AC, Meireles LM, Lemos MF, Guimarães MCC, Endringer DC, Fronza M, et al. Antibacterial activity of terpenes and terpenoids present in essential oils. Molecules. 2019;24:1-12.

25.Ju J, Xie Y, Yu H, Guo Y, Cheng Y, Zhang R. Synergistic inhibition effect of citral and eugenol against Aspergillus niger and their application in bread preservation. Food Chem [Internet]. 2020;310:1-7. Available from: https://doi.org/10.1016/j.foodchem.2019.125974

26.Qian W, Sun Z, Wang T, Yang M, Liu M, Zhang J, et al. Antimicrobial activity of eugenol against carbapenem-resistant Klebsiella pneumoniae and its effect on biofilms. Microb Pathog. 2020;139:1-9.

27. Cho JY, Choi GJ, Son SW, Jang KS, Lim HK, Lee $\mathrm{SO}$, et al. Isolation and antifungal activity of lignans from Myristica fragrans against various plant pathogenic fungi. Pest Manag Sci. 2007;63:935-940.

28.Rodianawati I, Hastuti P, Cahyanto MN. Nutmeg's (Myristica Fragrans Houtt) oleoresin: Effect of heating to chemical compositions and antifungal properties. Procedia Food Sci [Internet]. 2015;3:24454. Available from: http://dx.doi.org/10.1016/j.profoo.2015.01.027

29.Muchtaridi, Subarnas A, Apriyantono A, Mustarichie R. Identification of compounds in the essential oil of nutmeg seeds (Myristica fragrans Houtt.) that inhibit locomotor activity in mice. Int $\mathrm{J}$ Mol Sci. 2010;11(11):4771-81.

30.Baser KHC, Buchbauer G. Handbook of Essential Oils: Science, Technology, and Applications. CRC Press; 2009. 991 p.

31.Pillai S, Mahmud R, Lee WC, Perumal S. Antiparasitic activity of Myristica fragrans Houtt. essential oil against Toxoplasma gondii parasite. APCBEE Procedia [Internet]. 2012;2:92-6. Available from: http://dx.doi.org/10.1016/j.apcbee.2012.06.017

32.Das S, Kumar Singh V, Kumar Dwivedy A, Kumar Chaudhari A, Upadhyay N, Singh A, et al. Assessment of chemically characterised Myristica fragrans essential oil against fungi contaminating stored scented rice and its mode of action as novel aflatoxin inhibitor. Nat Prod Res [Internet]. 2018;15. Available from: https://doi.org/10.1080/14786419.2018.1519826

33.Adams RP. Identification of Essential Oils by Ion Trap Mass Spectroscopy. New York: Academic Press; 1989.

34.Carović-Stanko K, Orlić S, Politeo O, Strikić F, Kolak I, Milos M, et al. Composition and antibacterial activities of essential oils of seven Ocimum taxa. Food Chem. 2010;119(1):196-201.

35.CLSI. Clinical and Laboratory Standards Institute. Performance standards for antimicrobial susceptibility testing. 2007.

36.Magiatis P, Melliou E, Skaltsounis AL, Chinou IB, Mitaku S. Chemical composition and antimicrobial activity of the essential oils of Pistacia lentiscus var. chia. Planta Med. 1999;65(8):749-52.

37.CLSI. Reference method for broth dilution antifungal susceptibility testing of yeasts; approved standard third edition. M27-A3. Wayne. PA, USA; 2008.

38. Oliveira LBS, Batista AHM, Fernandes FC, Sales GWP, Nogueira NAP. Atividade antifúngica e possível mecanismo de ação do óleo essencial de folhas de Ocimum gratissimum (linn.) sobre espécies de Candida. Rev Bras Plantas Med. 2016;18(2):51123.

39.Kapadiya S, Desai MA. Isolation of Essential Oil From Buds of Syzygium aromaticum Using Hydrodistillation: Multi-Response Optimization and Predictive Modelling. Int $\mathbf{J}$ Adv Res Sci Eng. 2017;11:405-18.

40.Tao D, Li Y, Lu D, Luo Y, Yu S, Ye S. The essential 
oil components of Cinnamomum cassia: an analysis under different thinning models of plantation Pinus massoniana. J For Res. 2015;

41.Matulyte I, Jekabsone A, Jankauskaite L, Zavistanaviciute P, Sakiene V, Bartkiene E, et al. The essential oil and hydrolats from Myristica fragrans seeds with magnesium aluminometasilicate as excipient: Antioxidant, antibacterial, and antiinflammatory Activity. Foods. 2020;37(9).

42.Souza AA, Dias NAA, Piccoli RH, Bertolucci SKV. Composição química e concentração mínima bactericida de dezesseis óleos essenciais sobre Escherichia coli enterotoxigênica. Rev Bras Plantas Med. 2016;18(1):105-12.

43.Zhao X, Wu H, Wei J, Yang M. Quantification and characterization of volatile constituents in Myristica fragrans Houtt . by gas chromatography-mass spectrometry and gas chromatography quadrupoletime-of- fl ight mass spectrometry. Ind Crop Prod [Internet]. 2019;130(151):137-45. Available from: https://doi.org/10.1016/j.indcrop.2018.12.064

44.Schlemmer KB, Jesus FPK, Tondolo JSM, Weiblen C, Azevedo MI, Machado VS, et al. In vitro activity of carvacrol, cinnamaldehyde and thymol combined with antifungals against Malassezia pachydermatis. J Mycol Med [Internet]. 2019;29(4):375-7. Available from: https://doi.org/10.1016/j.mycmed.2019.08.003

45.Shreaz S, Bhatia R, Khan N, Muralidhar S, Basir SF, Manzoor N, et al. Spice oil cinnamaldehyde exhibits potent anticandidal activity against fluconazole resistant clinical isolates. Fitoterapia [Internet]. 2011;82(7):1012-20. Available from: http://dx.doi.org/10.1016/j.fitote.2011.06.004

46.Ranasinghe L, Jayawardena B, Abeywickrama K. Fungicidal activity of essential oils of Cinnamomum zeylanicum (L.) and Syzygium aromaticum (L.) Merr et L.M.Perry against crown rot and anthracnose pathogens isolated from banana. Lett Appl Microbiol. 2002;35(3):208-11.

47.Park M, Gwak K, Yang I, Choi W, Jo H, Chang J, et al. Antifungal activities of the essential oils in Syzygium aromaticum (L.) Merr. Et Perry and Leptospermum petersonii Bailey and their constituents against various dermatophytes. J Microbiol. 2007;45(5):460-5.

48.Pinto E, Vale-Silva L, Cavaleiro C, Salgueiro L. Antifungal activity of the clove essential oil from Syzygium aromaticum on Candida, Aspergillus and dermatophyte species. J Med Microbiol. 2009;58(11):1454-62.

49.Nardoni S, Najar B, Fronte B, Pistelli L, Mancianti F.
In vitro activity of essential oils against Saprolegnia parasitica. Molecules. 2019;24(7):6-13.

50.Rajkowska K, Nowicka-Krawczyk P, KunickaStyczynska A. Effect of clove and thyme essential oils on Candida biofilm formation and the oil distribution in yeast cells. Molecules. 2019;24(10):112.

51.Khan SN, Khan S, Misba L, Sharief M, Hashmi A, Khan AU. Synergistic fungicidal activity with low doses of eugenol and amphotericin B against Candida albicans. Biochem Biophys Res Commun [Internet]. 2019;518(3):459-64. Available from: https://doi.org/10.1016/j.bbrc.2019.08.053

52.Iyer M, Gujjari AK, Gowda V, Angadi S. Antifungal response of oral-associated candidal reference strains (American Type Culture Collection) by supercritical fluid extract of nutmeg seeds for geriatric denture wearers: An in vitro screening study Meenakshi. J Indian Prosthodont Soc. 2019;17(3):267-72.

53.Holley RA, Patel D. Improvement in shelf-life and safety of perishable foods by plant essential oils and smoke antimicrobials. Food Microbiol. 2005;22(4):273-92.

54.Tepe B, Daferera D, Sokmen A, Sokmen M, Polissiou M. Antimicrobial and antioxidant activities of the essential oil and various extracts of Salvia tomentosa Miller (Lamiaceae). Food Chem. 2005;90:333-40.

55.Miguel MG. Antioxidant and Anti-Inflammatory activities of essential oils: A short review. Molecules. 2010;15:9252-87.

56.Cai R, Hu M, Zhang Y, Niu C, Yue T, Yuan Y. Antifungal activity and mechanism of citral , limonene and eugenol against Zygosaccharomyces rouxii. LWT - Food Sci Technol [Internet]. 2019;106(January):50-6. Available from: https://doi.org/10.1016/j.lwt.2019.02.059

57.Sukcharoen O, Sirirote P, Thanaboripat D. Management of aflatoxigenic strains via vapor and contact treatment with essential oil obtained from Myristica Fragrans. Biotropia (Bogor). 2019;26(1):16-22. 